\title{
PROTAMINE (SALMINE) SULPHATE, HEPARIN, AND BLOOD COAGULATION
}

\author{
By A. FRANK PORTMANN AND WILLIAM D. HOLDEN
}

\author{
(From the Laboratory of Surgical Research, Western Reserve University, and University \\ Hospitals, Cleveland, O.)
}

(Received for publication March 24, 1949)

The availability of standardized preparations of heparin and their widespread clinical use in the treatment of thromboembolism have prompted us to reinvestigate the action of protamine sulphate on the coagulation of blood and its use as an antagonist to heparin.

For the past three decades the coagulation mechanism of blood has been represented by two equations (1):

$$
\begin{aligned}
& \text { 1. Prothrombin } \stackrel{\text { Thromboplastin }}{\underset{\text { Calcium }}{\longrightarrow} \text { Thrombin }} \\
& \text { 2. Fibrinogen } \stackrel{\text { Thrombin }}{\longrightarrow} \text { Fibrin }
\end{aligned}
$$

An enormous amount of investigative work performed within the past few years has effected numerous modifications in these two equations. The present concept of the coagulation mechanism consists of a system of circulating proteins and other macromolecules exhibiting complex inter-relationships and antagonisms which become imbalanced during the process of coagulation. The results of experiments with individual protein inter-actions call upon the biochemist, physiologist, and clinician for concise interpretation and critical evaluation, and then upon repeated experimentation before conclusions can be accepted as fact for either theoretic or practical consideration.

The present investigation of protamine sulphate began as a clinical problem, but it was realized early that interpretation of the results depended upon concepts of the coagulation mechanism which are controversial. The purpose of this paper is to present a series of in vivo and in vitro experiments which extend the existing knowledge of the action of protamine sulphate on the coagulation mechanism.
EFFECTS OF SALMINE ON THE NORMAL CLOTTING MECHANISM

Effects of in vivo injections of protamine sulphate on clotting times of whole blood samples subsequently obtained

At the onset of this project, little was known concerning the possible toxic or side reactions of protamine when it was administered intravenously in normal non-heparinized patients.

It has been demonstrated (2) that large doses of protamine administered intravenously in the dog resulted in the formation of multiple thrombi (emboli). In these experiments on humans, therefore, $10 \mathrm{mg}$. of protamine were initially given and the dose progressively increased to $100 \mathrm{mg}$. For one hour following the intravenous injection, the blood pressure, pulse, and respiratory rate were recorded at 10-minute intervals. The coagulaton time of the blood was determined by the Lee-White method before injection and at 10,20, and 60 minutes afterward. Blood specimens were drawn from a three-way stopcock through which a slow intravenous infusion of normal saline was given during the course of the experiments. This was done to minimize the introduction of tissue thromboplastic substance into the test tubes. The stopcock was back washed with normal saline after the withdrawal of blood or the injection of heparin or protamine. The heparin in most instances was administered in the contralateral arm. Twenty seconds after clamping the infusion tube, a saline washed $5 \mathrm{ml}$. syringe was filled with blood and a stop watch started. Three saline rinsed $11 \mathrm{~mm}$. test tubes were immediately filled with $1 \mathrm{ml}$. of blood. Coagulation was complete in each tube when the blood failed to flow on tilting with light tapping. The clotting times of the second and third tubes were averaged for recording. All determinations of clotting time were performed by the same technician. Results of these experiments are shown in Table I.

\section{Topical application of protamine}

Two dogs were anesthetized with intravenous sodium pentobarbital and areas $1 \mathrm{~cm}$. square were abraded on the skin, liver, gastric serosa and mu- 
TABLE I

Effect of intravenous protamine sulphate on the clotting time of whole blood

\begin{tabular}{l|c|c|c|c}
\hline \hline \multicolumn{1}{c|}{ Subjects } & \multicolumn{3}{|c}{ Clotting time in minutes } \\
\cline { 2 - 5 } & \multicolumn{3}{|c}{$\begin{array}{c}\text { Minutes after beginning } \\
\text { experiment }\end{array}$} \\
\cline { 2 - 5 } & $0^{\prime}$ & $10^{\prime}$ & $20^{\prime}$ & $60^{\prime}$ \\
\hline 10 Controls (Average) & 16.6 & 15.2 & 14.2 & 11.0 \\
$\begin{array}{l}\text { Nine Experiments with 10- } \\
60 \text { mg. Intravenous prota- } \\
\text { mine (Average) }\end{array}$ & 15.1 & 10.4 & 9.8 & 7.7 \\
$\begin{array}{l}\text { Acceleration of Clotting Time } \\
\text { in 10 Controls (Average) }\end{array}$ & 1.4 & 2.4 & 5.6 \\
$\begin{array}{c}\text { Acceleration of Clotting Time } \\
\text { in nine Protamine Experi- } \\
\text { ments (Average) }\end{array}$ & 4.7 & 5.3 & 7.4 \\
\hline
\end{tabular}

cosa. Bleeding from these areas was unaffected by the topical application of protamine when compared to adjacent control areas. Jorpes et al. (3) stated that protamine did not act as a local hemostatic agent in heparinized patients.

Effects of protamine on in vitro clotting systems

\section{Whole blood}

The effect of protamine on the clotting time of whole blood was observed by adding $2 \mathrm{ml}$. of whole blood immediately after withdrawal to increasing amounts of protamine sulphate. The clotdecelerating action of protamine is demonstrated in Table II. In all in vitro experiments the $\mathrm{pH}$

TABLE II

Anticoagulant action of protamine on whole blood in vitro

\begin{tabular}{c|c|c|c}
\hline \hline Tube No. & $\begin{array}{c}\text { Protamine } \\
\text { sulphate* }\end{array}$ & Clotting timet & Ratio P/F \\
\cline { 2 - 3 } 1 & mg. & minutes & \\
\cline { 2 - 3 } 2 & .01 & 9 & \\
3 & .02 & 9.5 & $.0025 / 1$ \\
4 & .1 & 10.5 & $.005 / 1$ \\
5 & .2 & 11 & $.025 / 1$ \\
6 & 1.0 & 15 & $.05 / 1$ \\
7 & 2.0 & 19 & $.25 / 1$ \\
8 & 10.0 & 52 & $.5 / 1$ \\
9 & 15.0 & $90 \mathrm{NC}$ & $2.5 / 1$ \\
10 & 20 & $90 \mathrm{NC}$ & $3.7 / 1$ \\
& & $5 / 1$ \\
\hline
\end{tabular}

* To each tube containing protamine sulphate was added: $2 \mathrm{ml}$. whole blood $+.85 \% \mathrm{NaCl}$ to constant volume.

$+\mathrm{NC}=$ No clot.

$\ddagger$ Ratio $\mathrm{P} / \mathrm{F}=$ protamine/fibrinogen. was $6.5-7.5$ and the temperature $25^{\circ}$ C. unless otherwise stated.

\section{Fibrinogen-thrombin mixtures}

Ferguson (4) previously pointed out a clot-accelerating effect of protamine when it was incubated with thrombin prior to the addition of fibrinogen. His work was corroborated. Experiments were then instituted to determine the effect of protamine on thrombin-fibrinogen mixtures in the presence of inactivated serum. Serum was inactivated by heating to $56^{\circ} \mathrm{C}$. for 10 minutes in a water bath. Following inactivation, the serum was tested for fibrinogen, thrombin, and prothrombin by adding respectively thrombin, fibrinogen, and a mixture of calcium chloride, thromboplastin, and fibri-

TABLE III

\begin{tabular}{ccc}
\multicolumn{3}{c}{$\begin{array}{c}\text { Effect of protamine on thrombin } \\
\text { in the presence of serum }\end{array}$} \\
Tube No.* & Protamine sulphate & Clotting timet \\
& mg. & seconds \\
1 & & 12.3 \\
2 & .02 & 13.7 \\
3 & .1 & 14.2 \\
4 & .2 & 13.8 \\
5 & .22 & 12.1 \\
6 & 1.0 & 8.6 \\
7 & 2.0 & 10.3 \\
$8 \ddagger$ & 4.0 & 41.2 \\
$9 f$ & 6.0 & $50 \mathrm{NC}$
\end{tabular}

* To each tube containing protamine sulphate was added: $.1 \mathrm{ml}$. human inactivated serum $+5 \mathrm{u}$. thrombin $+.85 \% \mathrm{NaCl}$ to constant volume. After five minutes' incubation of the mixture, $1.65 \mathrm{mg}$. fibrinogen were blown in and the clotting time determined.

$+\mathrm{NC}=$ No clot.

$\ddagger$ End point of clot formation indefinite.

nogen. No trace of fibrinogen, thrombin, or prothrombin was found. Serum inactivated in this manner does contain the heparin cofactor or substrate that heparin activates. This has been demonstrated elsewhere (5). Experiments were also set up to determine whether the five-minute incubation period produced any significant inactivation of the thrombin by the natural antithrombic activity of the serum. Control experiments, those with an incubation period of one minute and those with an incubation period of 11 minutes, produced clotting times of 12-13 seconds, on the addition of fibrinogen. Incubation periods beyond $10 \mathrm{~min}$ utes gave rise to more prolonged clotting times, up to 63 seconds after one hour of incubation.

There was no demonstrable accelerating effect of the protamine in tubes 2-5 (Table III). The 
concentration of protamine in these tubes corresponded generally with that necessary to effect neutralization of $.01 \mathrm{mg}$. of heparin in vitro. This is demonstrated subsequently in Table VII. In concentrations greater than this (tubes 6 and 7 , Table III) there was a slight but significant reduction of the clotting time. Quantities of protamine greater than $2 \mathrm{mg}$. in this mixture (tubes 8 and 9 , Table III) had a decided anticoagulant effect. In these two latter tubes, the ratio of protamine to fibrinogen was $2.4: 1$ and $3.6: 1$, and it will be shown that the inactivation of fibrinogen by the protamine produced this anticoagulant action.

\section{Fibrinogen precipitation}

Jaques (6) has shown that the protamineheparin complex behaves according to the law of mass action, and he was able to demonstrate an equivalence point using whole dog blood. An excess of either heparin or protamine caused prolongation of the clotting time. The antithrombic (7-9) and antiprothrombic (10) action of heparin in the presence of a cofactor has been demonstrated, but the clot-decelerating action of protamine in whole blood is less well understood. According to Mylon et al. (11), protamine will precipitate plasma fibrinogen, and they suggested that its principal anticoagulant effect obtains by means of this precipitation. Protamine in concentrations of $1.5 \mathrm{mg}$., and $10 \mathrm{mg} . / \mathrm{ml}$. of plasma will precipitate 80 per cent and 100 per cent of the plasma fibrinogen respectively. In order to study this effect, the experiment displayed in Table IV was performed.

The addition of thrombin in reaction 2, Table IV, to the supernatant fluid without the development of a fibrin clot in 30 minutes indicates that the supernatant fluid from reaction 1 either has no fibrinogen in it, or if it is present it is bound to

TABLE IV

\section{Dissociation of a protamine-fibrinogen complex in the presence of serum}

1. $8.25 \mathrm{mg}$. Fibrinogen $+6 \mathrm{mg}$. Protamine SulphateWhite Ppt. + Supernatant.

2. $.5 \mathrm{ml}$. Supernatant $+20 \mathrm{u}$. Thrombin-No Clot $30^{\prime}$.

3. $.5 \mathrm{ml}$. Supernatant $+20 \mathrm{u}$. Thrombin- $+1.65 \mathrm{mg}$. Fibrinogen-Clot $5^{\prime \prime}$

4. $.1 \mathrm{ml}$. Serum $+20 \mathrm{u}$. Thrombin-No Clot $30^{\prime}$.

5. $.5 \mathrm{ml}$. Supernatant $+20 \mathrm{u}$. Thrombin $+.1 \mathrm{ml}$. Serum -Clot $5^{\prime \prime}$.

* Fibrinogen $16.5 \mathrm{mg} . / \mathrm{ml}$. Protamine Sulphate 20 mg./ml. Thrombin $100 \mathrm{u} . / \mathrm{ml}$. Supernatant removed with a pipette.
TABLE $v$

Precipitation of fibrinogen by protamine in the presence of serum

\begin{tabular}{c|c|c|c}
\hline \hline Tube No.* & $\begin{array}{c}\text { Protamine } \\
\text { sulphate }\end{array}$ & Clotting time & Ratio P/Ft \\
\cline { 2 - 3 } 1 & $m g$. & seconds & \\
2 & 2 & 9 & $.25 / 1$ \\
3 & 4 & 5.3 & $.5 / 1$ \\
4 & 6 & 8.6 & $.75 / 1$ \\
5 & 8 & 17 & $1 / 1$ \\
6 & 10 & No clot & $1.25 / 1$ \\
7 & 12 & No clot & $1.5 / 1$ \\
8 & 14 & No clot & $1.8 / 1$ \\
9 & 16 & No clot & $2 / 1$ \\
\hline
\end{tabular}

* To each tube containing protamine sulphate was added: $8.25 \mathrm{mg}$. fibrinogen $+.2 \mathrm{ml}$. human inactivated serum $+.85 \% \mathrm{NaCl}$ to constant volume $+20 \mathrm{u}$. thrombin and the clotting time determined.

$\dagger$ Fibrin strands only. End point indefinite.

$\ddagger$ Ratio $\mathrm{P} / \mathrm{F}=$ protamine/fibrinogen.

the protamine. When less than $6 \mathrm{mg}$. of protamine were used in reaction 1 , a firm fibrin clot resulted from reaction 2 . Reaction 3 precludes the destruction of thrombin by the supernatant fluid. Reactions 4 and 5, however, indicate that fibrinogen must have been present in the supernatant fluid and that in the presence of serum, dissociation of a protamine-fibrinogen complex presumably occurred and liberated sufficient fibrinogen to permit the formation of a fibrin clot. According to the mass action law, a higher concentration of protamine would further suppress the presumed dissociation of a protamine-fibrinogen complex and eventually result in complete fibrinogen precipitation even in the presence of serum. This is shown in Table $\mathrm{V}$.

The approximate ratio of protamine to fibrinogen for complete inactivation in reaction 1 , Table IV, was .7:1, while in the presence of serum the ratio is $1.25: 1$. Similarly, in plasma, the ratio is 2.5:1 (11). The ratio for whole blood has not been determined, but from the protamine to heparin titration tables, it appears that in tubes containing a protamine excess insufficient to inactivate all the fibrinogen the anticoagulant action could not be dependent on the partial inactivation of fibrinogen, since the clotting time is not necessarily a function of fibrinogen concentration. It will later be shown that the tubes containing a slight excess of protamine will not clot on addition of fibrinogen. Thus it was felt that the inactiva- 
tion of fibrinogen was not the only acting anticoagulant action of protamine sulphate.

The above reactions were obtained with inactivated and active serum. The serum used did not clot within 20 minutes on addition of thromboplastin, calcium, and fibrinogen. Dissociation of the protamine-fibrinogen complex did not occur in solutions of thromboplastin or calcium chloride.

\section{Character of the anticoagulant action of protamine,} with special reference to antithromboplastic effects

Protamine may act as an antithromboplastin $(12,13)$ or an antiprothrombin $(4,12)$. To investigate these actions a series of in vitro experiments were carried out using whole blood. A quantity of protamine was used that would produce less than complete fibrinogen inactivation (Table VI).

Inactivation of the fibrinogen did not prevent clotting of the mixture of blood, sodium chloride, and protamine in tube 2 (Table VI) because the addition of an excess of fibrinogen in tube 3 had no significant effect. Further, the appearance of a normal fibrin clot in tubes 4 and 6 after the addition of thrombin showed that quantities of fibrinogen adequate for normal coagulation were present in solution. The results in tubes 7-12 indicated

TABLE VI

Character of anticoagulant action of protamine Added after 30 minutes' incubation of basic mixture*

\begin{tabular}{|c|c|c|c|c|c|c|}
\hline $\begin{array}{l}\text { Tube } \\
\text { No. }\end{array}$ & $\begin{array}{l}\text { Thrombo- } \\
\text { plastint }\end{array}$ & $\begin{array}{c}\text { Fibrino } \\
\text { gen }\end{array}$ & $\begin{array}{l}\text { Calcium } \\
\text { chloride } \neq\end{array}$ & $\begin{array}{c}\text { Thrombin } \\
\text { units }\end{array}$ & $\underset{\text { time }}{\text { Clotting }}$ & $\begin{array}{l}\text { Type of } \\
\text { clot }\end{array}$ \\
\hline & mg. & $m g$ & mg. & & minutes & \\
\hline 1 & - & - & 一 & 一 & $8 \S$ & Normal \\
\hline 2 & 一 & - & - & 一 & $>120^{\circ}$ & \\
\hline 3 & - & 9.9 & - & - & $>30$ & \\
\hline 4 & - & - & $\overline{0}$ & 20 & 20 & Normal \\
\hline 5 & - & - & .28 & $\bar{T}$ & $>120$ & \\
\hline 6 & - & - & .28 & $\mid \begin{array}{c}20(\text { atter } \\
\left.80^{\prime}\right)\end{array}$ & 20 & No \\
\hline 7 & 2.5 & - & .28 & - & 60 & Poor \\
\hline $\begin{array}{l}8 \\
9\end{array}$ & $\begin{array}{l}5.0 \\
7.5\end{array}$ & $\overline{1.65}$ & - & 二 & $\begin{array}{l}9.6 \\
5\end{array}$ & $\begin{array}{l}\text { Poor } \\
\text { Poor }\end{array}$ \\
\hline 10 & 12.5 & - & - & - & 2 & Normal \\
\hline 19 & $2.5 \pi$ & - & - & - & 42 & Poor \\
\hline & & 一 & 一 & 一 & 12 & Poor \\
\hline
\end{tabular}

$*$ Basic mixture $=2 \mathrm{ml}$. whole blood $+.2 \mathrm{ml} . .85 \%$ $\mathrm{NaCl}+16 \mathrm{mg}$. protamine sulphate.

t Thromboplastin (Maltine).

¥ Calcium chloride $.025 \mathrm{M}$.

Normal blood coagulation time. No protamine.

Added immediately to basic mixture.

II Incubated mixture of $5 \mathrm{mg}$. thromboplastin and $4 \mathrm{mg}$. protamine. that protamine interfered with the conversion of prothrombin to thrombin except in the presence of an excess amount of thromboplastin. The conversion of prothrombin to thrombin is inhibited but not destroyed.

\section{PROTAMINE-HEPARIN ANTAGONISMS}

The treatment of thromboembolism with heparin is widely accepted at the present time. Although serious accidents from injudicious use of heparin are decidedly uncommon, they do occur and will become more frequent as heparin is more generally used and as preparations prolonging the anticoagulant effect of heparin are developed. Chargaff and Olsen (14), who reported the neutralization of heparin by protamine in 1937, recognized its potential clinical application, but until recently protamine has been used more in experimental than clinical medicine.

The toxicity of large intravenous doses of protamine has been demonstrated in rabbits (15), rats (2), mice (16), dogs (17), and guinea pigs (18). Jaques et al. (19), in 1938, and more recently Parkin and Kvale (18) and Cowley and Lam (20) showed absence of toxicity in dogs when smaller but effective doses were used. Jorpes (3), using up to $60 \mathrm{mg}$. of protamine intravenously, in 1939 demonstrated the antagonism of protamine (clupein) for heparin in humans. Allen (21) has given $2.5 \mathrm{mg} . / \mathrm{kg}$. in man without ill effects.

Different preparations of protamine vary in their capacity to neutralize heparin. The protamine used in these experiments was Lot No. 8738 obtained from the Upjohn Company.

\section{Effect of intravenous protamine on heparinized patients}

Time intervals, controls, and blood specimens were identical with those described previously. The three-way stopcock method of obtaining blood was utilized.

Fifty mg. of heparin ${ }^{2}$ were administered intravenously-after a preliminary clotting time had been done. Ten minutes later, the protamine in doses of 10,30 , and $50 \mathrm{mg}$. was given intravenously. In each instance, the anticoagulant ef-

1 Abbott Laboratories. 


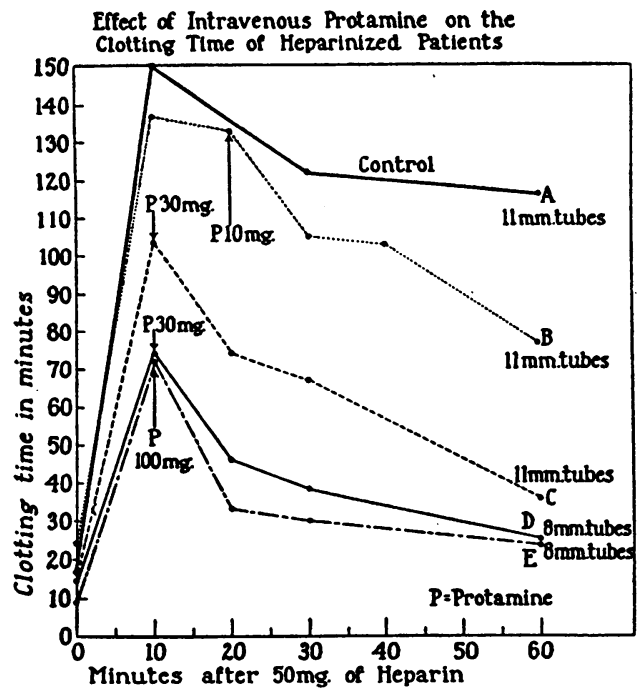

FIG. 1

fect of heparin was significantly reduced but not eliminated completely. Briefly, in 10 minutes 100 mg. of protamine produced approximately a 50 per cent decrease in the anticoagulant action of $50 \mathrm{mg}$. of heparin. The results in four cases are shown in Figure 1.

\section{Protamine-heparin neutralization in whole blood}

In order to verify the protamine-heparin ratio and investigate further the anticoagulant properties of protamine in vitro, titrations were carried out using normal blood. The same patient was used in all experiments.

Heparin, protamine, and normal saline were placed in a clean dry test tube. Two ml. of freshly drawn blood were added to each tube and the clotting time determined by formation of a visible clot in the cork-stoppered tubes. At low heparin and protamine concentrations, the end point of coagulation was readily apparent, but in high concentrations some clot formation was evident before the entire solution was coagulated. The stop watch was started when blood first appeared in the syringe. Table VII shows the titrations.

The protamine-heparin ratio at neutralization is somewhat higher in the more concentrated mixtures, Titrations No. 2 and No. 3, but these compare favorably with the serum titrations. Although the higher concentrations of protamine would never be encountered in vivo, the zone of maximum neutralization is nicely demonstrated. This occurs because, except near the equivalence point, a relatively large excess of heparin or protamine is free to exert its anticoagulant action. In the latter two titrations, the difference between the control coagulation time and the coagulation time at neutralization is widened. In tube 9, Titration No. 1, the experiment was repeated using isotonic sodium sulphate instead of sodium chloride in a concentration corresponding with that in tube 10, Titration No. 3, and no significant change in the clotting time occurred. It may be presumed, therefore, that the concentration of the sulphate ion in tube 10, Titration No. 3 , did not account for the elevated clotting time. No satisfactory explanation for this latter observation is apparent.

TABLE VII

Protamine-heparin titrations using $2 \mathrm{ml}$. of heparinized whole blood *

\begin{tabular}{|c|c|c|c|c|c|c|c|}
\hline \multirow{2}{*}{ Tube No. } & \multicolumn{2}{|c|}{ Titration No. 1} & \multicolumn{2}{|c|}{ Titration No. 2} & \multicolumn{2}{|c|}{ Titration No. 3} & \multirow{2}{*}{$\mathrm{P} / \mathrm{H}$ ratio } \\
\hline & $\begin{array}{l}\text { Mg. protamine } \\
\text { added to .01 } \\
\text { mg. heparin }\end{array}$ & C. T. & $\begin{array}{l}\text { Mg. protamine } \\
\text { added to .5 } \\
\text { mg. heparin }\end{array}$ & C. T. & $\begin{array}{l}\text { Mg. protamine } \\
\text { added to } 1.0 \\
\text { mg. heparin }\end{array}$ & C. $\mathrm{T}$. & \\
\hline $\begin{array}{r}1 \\
2 \\
3 \\
4 \\
5 \\
6 \\
7 \\
8 \\
9 \\
10 \\
11 \\
12 \\
13 \\
14 \\
15\end{array}$ & $\begin{array}{c}0 \\
.02 \\
.04 \\
.06 \\
.08 \\
.1 \\
.12 \\
.14 \\
.16 \\
.18 \\
.2 \\
- \\
\text { - } \\
\text { Control }\end{array}$ & $\begin{array}{l}31 \\
33 \\
22 \\
22 \\
18.8 \\
15.4 \\
14.1 \\
11.7 \\
14.3 \\
18.8 \\
19 \\
= \\
\overline{10.5}\end{array}$ & $\begin{array}{c}0 \\
1 \\
2 \\
3 \\
4 \\
\frac{6}{6} \\
\frac{8}{10} \\
12 \\
14 \\
16 \\
\text { Control }\end{array}$ & $\begin{array}{c}120 \mathrm{NC} \\
120 \mathrm{NC} \\
120 \mathrm{NC} \\
120 \mathrm{NC} \\
120 \mathrm{NC} \\
\overline{120 \mathrm{NC}} \\
\overline{14.5} \\
\frac{15}{21.5} \\
38 \\
120 \mathrm{NC} \\
10\end{array}$ & $\begin{array}{c}\frac{0}{4} \\
\frac{8}{8} \\
12 \\
14 \\
16 \\
18 \\
20 \\
24 \\
28 \\
\text { Control }\end{array}$ & $\begin{array}{c}120 \mathrm{NC} \\
120 \mathrm{NC} \\
120 \mathrm{NC} \\
- \\
120 \mathrm{NC} \\
120 \mathrm{NC} \\
63 \\
39 \\
43 \\
88 \\
89 \\
\frac{11}{11}\end{array}$ & $\begin{array}{r}2 / 1 \\
4 / 1 \\
6 / 1 \\
8 / 1 \\
10 / 1 \\
12 / 1 \\
14 / 1 \\
16 / 1 \\
18 / 1 \\
20 / 1 \\
24 / 1 \\
28 / 1 \\
32 / 1\end{array}$ \\
\hline
\end{tabular}

$* .85 \% \mathrm{NaCl}$ added to constant volume. C. $\mathrm{T}$. $=$ Clotting time in minutes. $\mathrm{NC}=$ No clot. 
Effects of protamine on heparin plus the serum heparin cofactor, tested on thrombin-fibrogen mixtures in vitro

Experiments were carried out to determine the protamine-heparin ratio that would effect neutralization of the latter in the presence of the serum heparin cofactor. A thrombin-fibrinogen mixture was used. Inactivated serum, previously referred to, was used in order to eliminate any antiprothrombin, antithromboplastic, or fibrinogen inactivating effect of the protamine. Serum inactivated by heating at $56^{\circ} \mathrm{C}$. for 10 minutes does not lose significant amounts of its heparin cofactor activity (5). Titrations are shown in Table VIII and Figure 2.

The addition of the protamine to the heparin first or to the serum first did not alter the final clotting times. Under normal circumstances over 90 per cent of the thrombin incubated with the serum and heparin will be destroyed in five minutes (5). The coagulation time of the system depends, in the absence of protamine, on the thrombin remaining after its partial destruction by the antithrombic activity of serum cofactor activated by heparin. An 18:1 ratio of protamine to

TABLE VIII

\begin{tabular}{ccc}
\multicolumn{3}{c}{ TABLE vill } \\
Protamine-heparin titration in serum \\
$\begin{array}{c}\text { Protamine } \\
\text { sulphate* } \\
\text { mg. }\end{array}$ & $\begin{array}{c}\text { Clotting time } \\
\text { seconds }\end{array}$ & Ratio P/H8 \\
- & $8.8 \dagger$ & \\
- & $32.7 \ddagger$ & \\
.01 & 26.8 & $1 / 1$ \\
.02 & 27.4 & $2 / 1$ \\
.03 & 25.8 & $3 / 1$ \\
.04 & 18.5 & $4 / 1$ \\
.05 & 16.7 & $5 / 1$ \\
.06 & 15.3 & $6 / 1$ \\
.07 & 16.3 & $7 / 1$ \\
.08 & 15.3 & $8 / 1$ \\
.09 & 12.1 & $9 / 1$ \\
.1 & 12.5 & $10 / 1$ \\
.12 & 9.9 & $12 / 1$ \\
.14 & 9.6 & $14 / 1$ \\
.16 & 9.8 & $16 / 1$ \\
.18 & 9.3 & $18 / 1$ \\
.2 & 8.2 & $20 / 1$ \\
.4 & 9.5 & $40 / 1$ \\
.8 & 7.6 & $80 / 1$ \\
1.2 & 7.3 & $120 / 1$
\end{tabular}

* To each tube containing protamine sulphate was added: $1 \mathrm{ml}$. human inactivated serum $+.01 \mathrm{mg}$. heparin +8 u. thrombin $+.85 \% \mathrm{NaCl}$ to constant volume. After five minutes' incubation of the mixture, $1.65 \mathrm{mg}$. fibrinogen was blown in and the clotting time determined.

+ Control clotting time without heparin or protamine.

$\mp$ Clotting time on addition of $.01 \mathrm{mg}$. heparin.

Ratio $\mathrm{P} / \mathrm{H}=$ protamine/heparin.

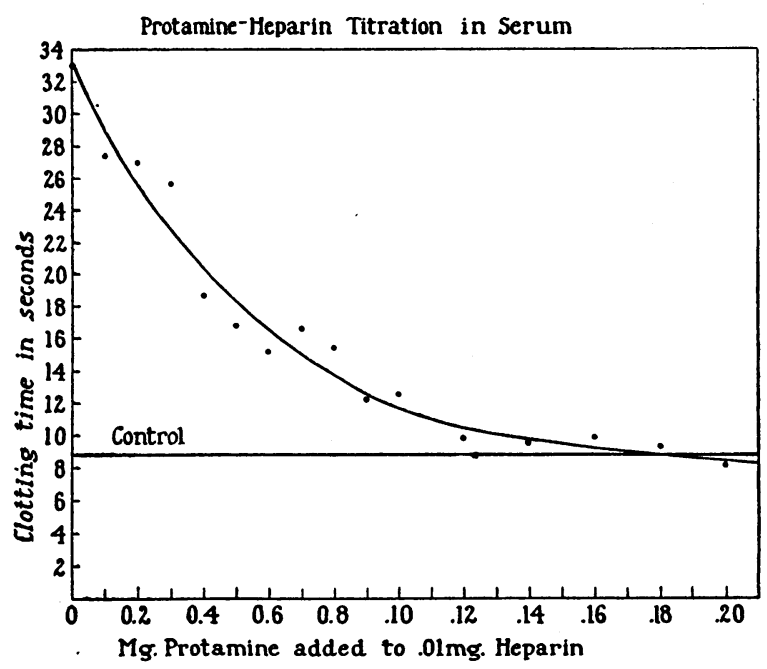

FIG. 2

heparin effected neutralization in repeated titrations. Increasing the ratio to $200: 1$ resulted in a slightly greater decrease in the coagulation time.

Action of thromboplastin on in vitro clotting of of whole blood in the presence of an excess of heparin or protamine

Experiments were set up to extend the observations made in Table VI on the effect of protamine and heparin on whole blood in vitro in the presence of an excess amount of thromboplastin. It had been noted in other experiments using recalcified plasma that the incubation of protamine with thromboplastin did not reduce the clot accelerating effect of the thromboplastin alone. Tubes 1, 4, 7 , and 14, Titration 2, Table VII, were repeated. After observing no clot for two hours an excess of thromboplastin was added to each tube. No clot occurred in tubes 1,4 , and 7 , but tube 14 clotted in 70 seconds. In tube 14 the heparin had apparently been neutralized and coagulation was inhibited by the excess of protamine which was overcome by the thromboplastin added.

\section{DISCUSSION}

There has been no observation in the literature to the effect that the intravenous administration of protamine will produce a shortening of the clotting time of the blood. Chargaff (14) reported that he was able to confirm the observation of Waldschmidt-Leitz and collaborators (22) that protamine had an inhibiting effect on blood clotting 
in vitro, but in dogs intravenous doses up to 11 $\mathrm{mg}$. $/ \mathrm{kg}$. failed to show any deviation of the clotting time from controls. Chargaff (23) later found that protamine did not alter the coagulation time of chicken plasma. Jaques (6) added protamine (.017 to $1.0 \mathrm{mg}$.) to $1 \mathrm{ml}$. of dog blood and demonstrated an anticoagulant effect with the higher concentrations. Cowley and Lam (20) reported a decreased coagulation time in a dog 30 minutes following $200 \mathrm{mg}$. of protamine, but no such effect was encountered with smaller quantities of protamine. The results of the experiments reported in this paper show a slight clot-accelerating "tendency" after the intravenous administration of protamine. Although the clotting times were performed with the utmost care in all experiments, it is our belief that technical variations account for the difference in clotting times between the controls and the protamine experiments. The only conclusion that can be arrived at, in accordance with the views of other investigators in this field, is that the intravenous administration of protamine has no clot-accelerating action in the absence of heparin.

The clot-decelerating effect of protamine on whole blood in vitro was demonstrated in Table II. In these experiments, there was no significant effect on the addition of protamine as long as the concentration of protamine corresponded to that found in whole blood after the intravenous administration of $100 \mathrm{mg}$. or less. As the protamine concentration in vitro is increased, however, there is a progressive prolongation of the clotting time. Although protamine in sufficient concentration will prevent clot formation by inactivating fibrinogen, the progressive prolongation of the clotting time in these experiments was not due to such inactivation since in few of the tests did the concentration of protamine in $2 \mathrm{ml}$. of whole blood attain high enough values. Since the rapidity with which coagulation occurs depends to a great extent on the amount of thrombin present, it appears that the anticoagulant effect of the protamine in these experiments was due to impaired thrombin formation.

Mylon, Winternitz, and de Sütö-Nagy (11) demonstrated that protamine will precipitate fibrinogen. The experiments performed and indicated in Tables IV and V demonstrate that protamine precipitates fibrinogen but in addition forms a soluble fibrinogen-protamine complex that in the presence of inactivated serum makes available sufficient fibrinogen to allow coagulation on the addition of thrombin. When the concentration of protamine is increased, dissociation of the fibrinogen-protamine complex is inhibited and coagulation prevented. When referring to the effect of protamine on the second stage of coagulation, we prefer to use the term "protamine inactivating effect on fibrinogen" rather than "protamine precipitating effect."

Experiments listed in Table VI suggest that protamine interferes with the conversion of prothrombin to thrombin in whole blood except in the presence of an excess amount of thromboplastin. Tubes $2,7,8$, and 12 indicate that the interference with the conversion of prothrombin to thrombin by the protamine is not an antithromboplastic effect. Conclusions beyond these cannot be drawn without determining the effect of protamine on a clotting system containing purified prothrombin.

The in vivo effect of protamine on heparinized patients duplicated the results of previously reported observations by others and needs no comment. It should be stated, however, that any clinician using protamine to neutralize heparin in vivo should be thoroughly acquainted with the character and strength of the protamine preparation he is utilizing. Preparations may vary considerably in their capacity to neutralize heparin. It also appears that the neutralization of a certain quantity of heparin in vivo may require considerably less protamine than is necessary for neutralization in vitro.

The neutralization of heparin by protamine in whole blood in vitro is listed in Table VII. Neutralization was effected with a protamine-heparin ratio of approximately $16: 1$. The protamine used in these experiments was Lot No. 8738 (Upjohn). A preparation subsequently obtained (Lot No. 8960 Upjohn) showed an in vitro protamineheparin ratio of $0.7: 1$.

The neutralization of heparin was also determined in an isolated clotting system containing fibrinogen, thrombin, the serum heparin cofactor, heparin, protamine, and saline (Table VIII). Neutralization was complete at a protamineheparin ratio of $20: 1$, which agrees satisfactorily with the 18:1 ratio observed in whole blood (Table VII). It is apparent from the observa- 
tions made in these experiments plus those made from the same isolated system without the addition of heparin that protamine has no significant effect upon the heparin cofactor.

\section{SUMMARY}

1. Protamine sulphate administered intravenously in doses up to $100 \mathrm{mg}$. in humans has no effect upon the clotting time of whole blood.

2. Protamine sulphate had no effect as a local hemostatic agent in dogs.

3. In relatively low concentrations in inactivated serum, protamine has a clot-accelerating effect on a thrombin-fibrinogen mixture after incubation of the thrombin with protamine.

4. The antagonism to heparin was demonstrated in vitro and in vivo. In the presence of serum or whole blood, the protamine-heparin ratio at neutralization was 18:1. An excess of either caused prolongation of the coagulation time.

5. When present in whole blood in concentration insufficient to cause complete inactivation of fibrinogen, the anticoagulant effect of protamine is due to its interference with the conversion of prothrombin to thrombin. This antiprothrombic effect is not apparent in the presence of an excess of thromboplastin.

6. An antithromboplastic action of protamine sulphate could not be demonstrated.

7. Protamine does neutralize the serum heparin cofactor.

\section{BIBLIOGRAPHY}

1. Wöhliscn, E., Die physiologie und pathologie der blutgerinnung. Ergebn. d. Physiol., 1929, 28, 443.

2. Shelley, W. B., Hodgkins, M. P., and Visscher, M. B., Studies on toxicity of protamine. Proc. Soc. Exper. Biol. \& Med., 1942, 50, 300.

3. Jorpes, E., Edman, P., and Thaning, T., Neutralization of action of heparin by protamine. Lancet, 1939, $2,975$.

4. Ferguson, J. H., The action of heparin, serum albumin (crystalline) and salmine on blood-clotting mechanisms (in vitro). Am. J. Physiol., 1940, 130, 759.

5. Holden, W. D., Cole, J. W., and Davis, J. H., Jr., Clinical studies of the heparin cofactor. Surg., Gynec. \& Obst., in press.

6. Jaques, L. B., The reaction of heparin with proteins and complex bases. Biochem. J., 1943, 37, 189.
7. Howell, W. H., The purification of heparin and its presence in blood. Am. J. Physiol., 1924, 71, 553.

8. Quick, A. J., The normal antithrombin of the blood and its relation to heparin. Am. J. Physiol., 1938, $123,712$.

9. Ziff, M., and Chargaff, E., The mechanism of the action of heparin. Proc. Soc. Exper. Biol. \& Med., 1940, 43, 740.

10. Brinkhous, K. M., Smith, H. P., Warner, E. D., and Seegers, W. H., The inhibition of blood clotting: an unidentified substance which acts in conjunction with heparin to prevent conversion of prothrombin into thrombin. Am. J. Physiol., 1939, $125,683$.

11. Mylon, E., Winternitz, M. C., and deSütö-Nagy, G. J., The determination of fibrinogen with protamine. J. Biol. Chem., 1942, 143, 21.

12. Tocantins, L. M., Cephalin, protamine and the antithromboplastic activity of normal and hemophilic plasmas. Proc. Soc. Exper. Biol. \& Med., 1943, 54, 94.

13. Chargaff, E., The protamine salts of phosphatides, with remarks on the problem of lipoproteins. J. Biol. Chem., 1938, 125, 661 .

14. Chargaff, E., and Olson, K. B., Studies on the chemistry of blood coagulation. VI. Studies on action of heparin and other anticoagulants. The influence of protamine on the anticoagulant effect in vivo. J. Biol. Chem., 1937, 122, 153.

15. Vartiainen, I., and Marble, A., The effect of the subcutaneous administration of protamine (salmine) to rabbits and mice. J. Lab. \& Clin. Med., 1941, 26, 1416.

16. Reiner, L., de Beer, E. J., and Green, M., Toxic effects of some basic proteins. Proc. Soc. Exper. Biol. \& Med., 1942, 50, 70.

17. Thompson, W. H., Die Physiologische Wirkung der Protamine und ihrer Spaltungsprodukte. Ztschr. f Physiol. Chem., 1900, 29, 1.

18. Parkin, T. W., and Kvale, W. F., Neutralization of heparin with protamine (salmine). J. Lab. \& Clin. Med., 1947, 32, 1396.

19. Jaques, L. B., Charles, A. F., and Best, C. H., The administration of heparin. Acta med. Scandinav., Supp., 1938, 90, 190.

20. Cowley, L. L., and Lam., C. R., The neutralization of heparin by protamine. Surgery, 1948, 24, 97.

21. Allen, J. G., Bogardus, G., Jacobson, L. O., and Spurr, C. L., Some observations on bleeding tendency in thrombocytopenic purpura. Ann. Int. Med., 1947, 27, 382.

22. Waldschmidt-Leitz, E., Stadler, P., and Steigerwaldt, F., Uber blutgerinnung. Ztschr. f. Physiol. Chem., 1929, 138, 39.

23. Chargaff, E., Studies on the chemistry of blood coagulation. VII : protamines and blood clotting. J. Biol. Chem., 1938, 125, 671. 